\title{
Desenvolvimento das Habilidades do Pensamento AcadêMico
}

\section{Zwiers,J. (2004). Developing Academic Thinking Skills in grades 6 - 12: a handbook of multiple intelligence activities. Newark: IRA, xii +260 p.}

Jeff Zwiers é consultora e professora que trabalha com linguagem e leitura estando envolvida com formação de professores especialmente em termos de desenvolvimento da linguagem acadêmica e de conteúdos específicos.

O livro aqui resenhado tem um suporte teórico conceitual mas é predominantemente prático. Constituído por prefácio três partes, apêndices e índices é uma ferramenta de grande utilidade para professores não só de leitura mas de todas as matérias que integram o currículo. A validade de tecnologias e procedimentos que apresenta esta livre de cegueira teórica o que indica uma posição moderna, atitude eclética e um grande potencial de generalização. São formas de assegurar o desenvolvimento de habilidades cognitivas importantes na formação não apenas do leitor, embora a ênfase no livro seja as suas relações com a vida acadêmica. A preocupação de Zwiers é com as habilidades a serem ensinadas e como ensiná-las, o que faz com clareza e competência. Cabe aos professores a tarefa de propiciar o desenvolvimento destas habilidades nos seus alunos.

A primeira parte do livro é constituída por dois capítulos de cunho teórico sendo que no primeiro deles é feita uma apresentação comparativa entre linguagem e pensamento acadêmicos. Há consenso na maioria dos pesquisadores de que existem muitas habilidades de pensamento e que elas devem ser desenvolvidas na escola. Para tanto, há necessidade de instrumentar os docentes não só com informações sobre estas habilidades e como elas se relacionam entre si mas como fazer para que se desenvolvam. Vale lembrar que pensamento, linguagem e aprendizagem de conteúdo são simbólicos, devendo haver uma adequação da vida acadêmica. As habilidades de pensar não são igualmente requeridas nas várias áreas de conteúdo sendo necessário recorrer a formas distintas para que se desenvolvam adequadamente em Ciências, História, Estudos Sociais e nas várias linguagens. As principais habilidades do pensamento acadêmico são: analisar, comparar, identificar causa e efeito, categorizar e classificar, solucionar problemas, persuadir, empatizar, sintetizar, interpretar, avaliar, comunicar, e aplicar. Seqüências e atividades diversas específicas de cada área de conhecimento são consideradas em cada caso.

No segundo capitulo são enfocados os hábitos que um professor precisa ter para que possa propiciar ao aluno o desenvolvimento requerido. As pesquisas mostram que os hábitos docentes mais poderosos e necessários para o desenvolvimento das habilidades de pensar academicamente são: (1) ir da avaliação para a instrumentação; (2) oferecer possibilidade de escolhas para aprender; (3) relacionar o novo com o já existente; (4) modelar o pensamento; (5) gradualmente passar a responsabilidade para o aluno (modelagem); (6) dar miniaulas sobre pensamento acadêmico e linguagem; (7) usar linguagem acadêmica apropriada para eliciar e cultivar o pensamento acadêmico; (8) estabelecer transição entre as lições e atividades; (9) cuidar tanto dos aspectos verbais como dos não verbais do ensino e (10) manter uma coleção crescente de exemplos das melhores práticas acadêmicas.

A parte seguinte do livro enfoca 12 habilidades do pensamento acadêmico, sendo a maior e a mais central da obra. O capitulo 3 traz informações básicas sobre o analisar e como desenvolver esta habilidade no pensamento acadêmico, como por exemplo a análise de modelos de escrita, o uso de organizadores e mapeamento semânticos, cartas biológicas e outras técnicas de ensino de eficiência já comprovada.

O capítulo 4 enfoca as habilidades de fazer comparações e, após breve conceituação, várias tecnologias são disponibilizadas para que o professor possa ter êxito. 
Pode-se exemplificar com a grade de comparação, uso de simulações de sinestezias, uso de músicas e textos.

Categorizar e classificar implica em uma habilidade básica na vida sendo necessário desenvolvê-la de forma útil às diversas áreas de conteúdo, nas várias tarefas acadêmicas. Sugere o uso de colunas de classificação, classes de sentenças e orações, estocagem da idéia principal, classificação de músicas etc.

No capitulo seguinte são feitas propostas que condições para que os alunos aprendam e desenvolvam a habilidade de pensar sobre causa e efeito. Entre elas aparecem: criação de diagramas, uso de organizadores visuais, levantamento de hipóteses, uso da linha do tempo etc.

A habilidades de solução de problemas é o foco do sétimo capítulo no qual são sugeridas atividades como uso dos lados direito-esquerdo do cérebro, planejamento de vídeo games, solução de classificações, solução por emparelhamento, solução pelo método científico, entre outros.

Como bem lembra Zwiers (p: 105) a vida é cheia de persuasão "sendo necessário desenvolver esta habilidade nos alunos". Para tanto, recomenda estratégias como: balão cheio de ar quente, reestruturação, reconstrução, busca das razões etc. (capitulo 8).

No capitulo 9 é enfocada a habilidades de empatia, útil não só para as habilidades sociais uma vez que perpassa toda a capacidade de pensar e se sair bem na escola. Ela tem sido uma habilidade muito valorizada na aprendizagem de conceitos, na compreensão de outras pessoas e de como pensam e sentem. Pode ser desenvolvida recomendando estratégias como desempenho de papéis, cadeira quente, encontro para o chá, redação científica, interpretação e análise de texto literário.

Fazer síntese é a habilidade complexa considerada no décimo capitulo. Implica em extrair informações de diferentes fontes, combiná-las com as já conhecidas, fazendo emergir novos padrões e conceitos. É considerada uma das habilidades mais criativas do pensamento e possivelmente uma das mais difíceis de ensinar. Entre as atividades propostas para desenvolver a habilidade de síntese aparecem: criar jogos educacionais, reformular jogos e regras, fazer notas de síntese, transformar texto etc.

A interpretação (capitulo 11) é uma habilidade requerida constantemente na vida posto que é usada para dar sentido tanto a pequenos como a grandes indícios, criando o mundo pessoal de cada um. A interpretação é muito requisitada na vida acadêmica enfocando textos, dados observáveis, figuras, números, mapas etc. Práticas que a desenvolvem são: arte de interpretação triangular, técnica de interpretação de figura, representação de metáforas (textos ou outra forma) etc.

No capitulo seguinte, a avaliação é o foco da atenção. Ela é importante para que o aluno tenha êxito na vida acadêmica, implicando em saber atribuir valor a alguma coisa ou parte dela de acordo com algum critério, o que é ao mesmo tempo sua característica mais marcante e difícil de ser estabelecida. Pode ser desenvolvida pelo uso de gráficos, pontuações de avaliações, diagramas, simulações diversas.

O objeto de atenção do capitulo 13 é a comunicação, a qual como lembra Zwiers, nem sempre aparece nas listas de habilidades do pensamento. Todavia, muito do pensamento e da criatividade requer a habilidade de fazer comunicação oral, escrita ou não verbal. Está diretamente ligada ao desenvolvimento da linguagem acadêmica (processo e produto). Pode ser desenvolvida usando-se várias técnicas de trabalho em grupo, de experiências verbais, de discussões de diversos tipos, técnica do professor "não veio", pares de pensadores, código colorido de escrita, entre outras.

O último capítulo da segunda parte trata da aplicação que requer saber $o$ que, o quanto e o como aplicar o que se aprendeu. Tem papéis diferentes nas várias áreas de conhecimento mas é considerada o coração ou responsável pelo êxito das habilidades do pensar. Sem aplicação do aprendido não se pode dizer que o processo se completou. Procedimentos diversos de generalização auxiliam no desenvolvimento desta habilidade. Exemplo: desempenho em tarefas planejadas com o auxilio dos estudantes, projetos no mundo real, ensinar estudantes mais jovens, desempenho de papéis etc.

A terceira parte contém uma série de documentos, fichas, esquemas, quadros que o professor tem autorização para reproduzir e usar em suas aulas, facilitando o emprego das sugestões e orientações para o desenvolvimento das atividades propostas no livro. Elas também facilitam dispor de material para pesquisar as técnicas e procedimentos. Como são atividades não exploradas no Brasil, sem dados científicos colhidos em sua realidade social cultural e educacional, seria muito importante pesquisar a validade, a precisão e a eficácia nas escolas brasileiras. 
Os três apêndices são muito úteis para se repensar o processo educativo. O primeiro traz um rol de atividades para o desenvolvimento das inteligência múltiplas nos campos artísticos-viso-espacial, musical, cinestésicocorporal, socio-interpessoal, auto-intrapessoal, matemático-lógico, científico-natural e verbal. O segundo apêndice arrola questões para trabalhar tópicos controversos filosóficos, culturais, verbais, históricos, políticos, científicos e comerciais. O último apresenta uma lista de sons que podem servir de base para canções.

As referências usadas incluem clássicos mas predominam obras recentes, várias publicadas em periódicos, que poderiam ser em maior número, mas se justifica pelo caráter predominantemente prático da obra. Há ainda uma relação com obras literárias citadas e outra com sugestões de textos complementares para quem desejar se aprofundar.

A consulta à obra é facilitada por um índice de autores e conteúdo e por uma lista das atividades organizadas por capítulos e por ordem alfabética.

O livro abre perspectiva para ensino e pesquisa, sugestões devidamente sustentadas em dados podem renovar substancialmente a educação. Cabe formar docentes com competências para tanto.

Geraldina Porto Witter Universidade Mogi das Cruzes 